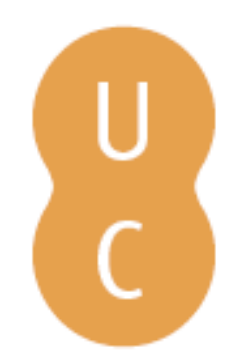

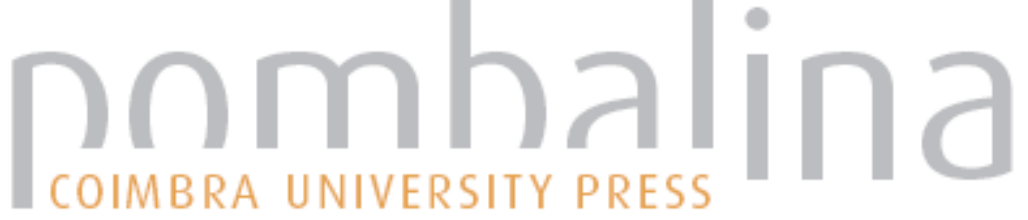

\section{Democracia e o cidadão ideal: o retrato do cidadão no Contra Leócrates}

Autor(es): $\quad$ Leite, Priscilla Gontijo

Publicado por: Imprensa da Universidade de Coimbra

URL

persistente: URI:http://hdl.handle.net/10316.2/45151

DOI: $\quad$ DOl:https://doi.org/10.14195/978-989-26-1679-7_8

Accessed : $\quad$ 26-Apr-2023 15:15:23

A navegação consulta e descarregamento dos títulos inseridos nas Bibliotecas Digitais UC Digitalis, UC Pombalina e UC Impactum, pressupõem a aceitação plena e sem reservas dos Termos e Condições de Uso destas Bibliotecas Digitais, disponíveis em https://digitalis.uc.pt/pt-pt/termos.

Conforme exposto nos referidos Termos e Condições de Uso, o descarregamento de títulos de acesso restrito requer uma licença válida de autorização devendo o utilizador aceder ao(s) documento(s) a partir de um endereço de IP da instituição detentora da supramencionada licença.

Ao utilizador é apenas permitido o descarregamento para uso pessoal, pelo que o emprego do(s) título(s) descarregado(s) para outro fim, designadamente comercial, carece de autorização do respetivo autor ou editor da obra.

Na medida em que todas as obras da UC Digitalis se encontram protegidas pelo Código do Direito de Autor e Direitos Conexos e demais legislação aplicável, toda a cópia, parcial ou total, deste documento, nos casos em que é legalmente admitida, deverá conter ou fazer-se acompanhar por este aviso. 

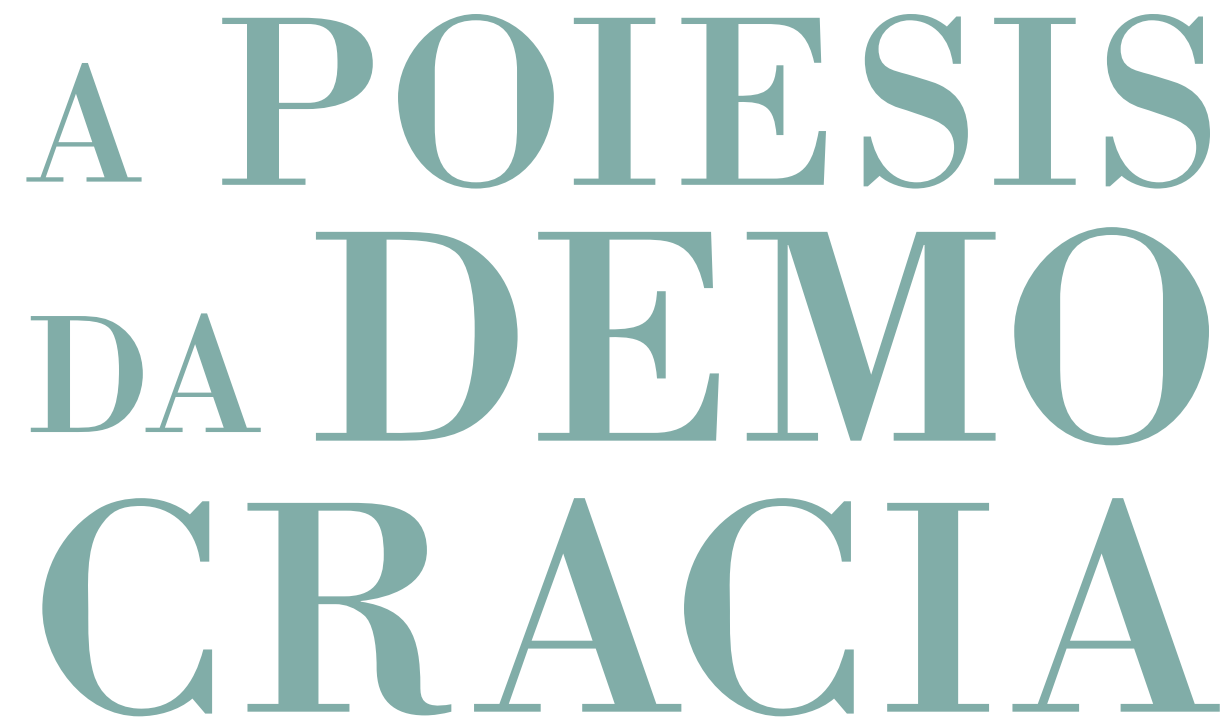

G

Breno Battistin Sebastiani, Delfim Leão,

Lugia Sano, Martinho Soares, Christian Werner

\section{CoimbraCompanions}




\section{Democracia e o cidadão ideal:}

O RETRATO DO CIDADÃO NO CONTRA LEÓCRATES

\section{DEMOCRACY AND THE IDEAL CITIZEN :}

THE PORTRAIT OF THE CITIZEN IN THE AGAINST LEOCRATES

Priscilla Gontijo Leite Universidade Federal da Paraíba ORCID | 0000-0003-2616-7186 


\section{Resumo}

A organização das instituições democráticas na Atenas Clássica permitiu que o campo jurídico fosse utilizado nas disputas políticas, fazendo com que houvesse nos julgamentos uma preocupação com a construção do ethos do orador e de seu adversário. A construção dessa imagem não serviria apenas para ganhar a causa em disputa, mas contribuiria também para o desenvolvimento da imagem de como o cidadão deveria agir na democracia. Por isso, era importante enfatizar as ações benéficas e prejudicais à democracia, mesmo quando elas não fossem diretamente ligadas à causa em julgamento. O objetivo do presente trabalho é analisar a construção do ethos do bom e do mau cidadão no discurso Contra Leócrates de Licurgo, datado de 330 a.C. O discurso se passa logo após a Batalha de Queroneia, em meio aos sentimentos de incerteza dos atenienses sobre as ações de Filipe II com relação à cidade. Por essa razão, ele constitui uma valiosa fonte para entender o processo de mudança na mentalidade ateniense diante das transformações ocorridas na polis provocadas pela expansão do poder macedônico. Apesar dessas transformações, nota-se a permanência na construção do ethos a respeito do cidadão, bem como o impacto que esses modelos provocavam nos habitantes da polis.

\section{Palavras-chave}

Licurgo, retórica, cidadania, ethos, democracia 


\section{Abstract}

The organization of the democratic institutions in Classical Athens allowed the legal field to be used in political disputes. In trials, there was a concern with the construction of the ethos of the speaker and his opponent. The construction of this image would serve not only to win the case in dispute, but would also develop an image of how the citizens should act within the democracy. Therefore, it was important to emphasize actions that were beneficial and harmful to the democracy, even when they were not directly linked to the cause in judgment. The aim of this study is to analyze the construction of the ethos of the good and bad citizens in Lycurgus's speech Against Leocrates (330BC). The speech was delivered shortly after the Battle of Chaeronea, amid the Athenians' feelings of uncertainty over the actions of Philip II regarding the city. For this reason, it constitutes a valuable source for understanding the process of change of the Athenian mentality in the face of the polis' transformations caused by Macedonian expansion. Despite these transformations, the permanence in the construction of the ethos of the citizen is discernible, as well as the impact that these models caused for inhabitants of the polis.

\section{Keywords}

Lycurgus, rhetoric, citizenship, ethos, democracy 
$\mathrm{Na}$ atualidade, o regime democrático é uma das formas de governo mais difundidas do mundo, sendo adotado por aproximadamente $45 \%$ dos países. A adesão a ela também cresceu de forma espantosa, registrando um aumento de $18 \%$ nos últimos dez anos. ${ }^{1} \mathrm{~A}$ adoção legal do sistema democrático não significa, entretanto, a incorporação de práticas ligadas ao exercício da democracia, idealizado no seu surgimento na Grécia Antiga, como a igualdade de acesso à justiça - isonomia - ou a intensa participação nos negócios públicos - isegoria e isocracia. Hoje, a participação mais usual em várias democracias é restrita à possibilidade de escolha de um representante. No sistema representativo, a retórica cumpre um papel importante ao garantir a vitória na eleição, pois está ligada à capacidade de convencimento do candidato, que mobiliza os instrumentos ao seu alcance, seja um discurso bem elaborado (campo da retórica), recursos financeiros ou sua inserção em alianças políticas. Os dois últimos pontos não serão aprofundados por fugir do escopo da nossa análise.

Com o foco no primeiro ponto, o convencimento por meio do discurso, analisaremos o topos da construção de um argumento retórico pautado na caracterização do bom e do mau cidadão e de sua eficiência no jogo político, assegurando a vitória de um determinado grupo. Essa perspectiva de análise urge de uma demanda do tempo presente, em particular da realidade brasileira. Voltando-se o olhar para alguns aspectos do sistema político brasileiro, nota-se a imprescindível tarefa de repensar a relação entre representatividade e democracia, pois, nas eleições para prefeitos e vereadores de 2016, o número de votos inválidos (brancos, nulos e abstenções) superou o candidato eleito para a prefeitura em primeiro ou segundo lugar em 22 
capitais ${ }^{2}$ indicando uma descrença com o sistema político vigente. As razões históricas para essa descrença são múltiplas e complexas, mas um fenômeno mais recente não deve ser desconsiderado e ele se relaciona diretamente com a construção retórica do topos do "bom e mau cidadão". Nos últimos anos, percebeu-se a representação pela mídia de uma narrativa que polariza os brasileiros em dois grandes grupos: de um lado, os "cidadãos de bem"; de outro, a esquerda. Em outras palavras, para utilizar o jargão baseado em critérios alimentícios e que caiu no gosto popular, vimos o aparecimento de termos como "coxinha" e "mortadela". Tais rótulos são redutores para explicar toda a dinâmica que envolve esses dois grandes grupos, pois não são capazes de expressar a heterogeneidade de cada um. Essa complexidade, por si só, renderia um pesquisa própria, que foge do escopo pretendido aqui. Apenas destacamos que, em linhas gerais, esses termos ajudam a pensar em alguns valores que cada um atribui a si e ao outro, bem como os critérios utilizados para definir o modelo apropriado de cidadão, pautado principalmente no combate a corrupção.

As narrativas criadas por esses grupos e sobre eles demonstraram disputas políticas e as diferentes estratégias de ocupação e manutenção de poder. Desde 2013, segmentos tradicionais da mídia brasileira referendam e apoiam determinadas manifestações, colocando-as como legítimas e motivadas pela defesa do país a partir de sua caracterização como ordeiras e pacíficas. Outras somente teriam a intenção de provocar distúrbios e, nesses casos, o foco da notícia é o vandalismo das ações dos participantes. Essa dicotomia, porém, não está presente apenas no discurso midiático. Em um relatório apresentado pela OEA sobre a atuação da Polícia Militar nas manifestações desde 2013, constatou-se que a polícia tem "caráter discriminatório" de acordo com "expressão ideológica" do grupo envolvido, facilitando algumas manifestações e reprimindo outras, o que fere gravemente o direito de expressão, um dos pilares da democracia. ${ }^{3}$

2 Disponível em http://www.bbc.com/portuguese/brasil-37514671. Acesso em 04/10/2016. No caso da capital de Minas Gerais, os votos inválidos superam a soma dos votos do primeiro e segundo candidatos; já na capital de São Paulo, os votos inválidos superam os votos do prefeito eleito.

3 Disponível em http://noticias.uol.com.br/politica/ultimas-noticias/2016/10/05/oea-pmfacilita-ou-reprime-protestos-conforme-a-ideologia-de-manifestantes.htm. Acesso em 05/10/2016. 
A partir dessa problemática, i. e. a construção da polaridade entre bons e maus cidadãos, direcionaremos nosso olhar para a Antiguidade Clássica, mais especificamente para o caso ateniense, objeto central da análise. É possível entender a democracia ateniense do século IV a.C., transformada após a derrota da Guerra do Peloponeso, por meio dos discursos áticos, que revelam ser uma fonte rica em exemplos de como se deve portar o bom cidadão e sua antítese, sendo esse um topos utilizado para o convencimento da punição do adversário. ${ }^{4}$ Uma síntese do comportamento idealizado em relação à cidadania encontra-se no relato de Ésquines, que se retrata com essas características em oposição a Demóstenes, seu inimigo político e pessoal: 5

Todos vós, creio eu, admitis serem estes os característicos do democrata: primeiro, ser de condição livre tanto da parte do pai, como da parte da mãe, não vá a infelicidade da origem torná-lo hostil às leis, salvação da democracia; em segundo lugar, ter um de seus avós prestado algum benefício ao povo ou, necessariamente, não terem pelo menos dado nenhum motivo de ódio; assim não virá a tentar algum malefício à república para vingar as desventuras dos seus maiores; em terceiro lugar, ser de gênio prudente e moderado em sua vida cotidiana, não seja a desordem dos gastos de se deixar subornar em dano ao povo; em quarto lugar, ser atinado e eloquente; bom é que o discernimento escolha o melhor partido, e a instrução e eloquência do orador convençam os ouvintes; se não, ao menos prevaleça o tino sobre a eloquência; em quinto lugar, ter alma viril para não abandonar o povo na hora da calamidade e do perigo. ${ }^{6}$

No relato, percebe-se que a primeira preocupação do bom democrata é não ser hostil às leis. Um bom cidadão deve sempre mostrar o respeito às

\footnotetext{
4 Aeschin. 1. 1-8; 3. 214-240; D. 21. 98, 148-50, 159.

5 Para mais informações sobre a contenda entre Demóstenes e Ésquines e o desenvolvimento de recursos retóricos, vide Leite 2014: 259-310.

6 Aeschin. 3. 169-170. Para as citações do discurso, utilizaremos a tradução de Bruna (1997).
} 
leis, sendo elas consideradas essenciais para a manutenção da democracia, ${ }^{7}$ já que asseguram a incolumidade aos cidadãos. ${ }^{8} \mathrm{~A}$ moderação na vida privada também é recomendada, pois um cidadão que trata de seus assuntos privados de forma inapropriada estaria mais propenso não só a cometer erros na esfera pública, como a aceitar mais facilmente o suborno. O aspecto retórico também é essencial para a formação do bom cidadão, uma vez que na democracia a ação política se dá por meio da palavra. O bom democrata sabe utilizar habilmente as palavras, expondo-as de forma clara e precisa, mostrando uma sintonia com a vontade do demos para que a decisão tomada não precise ser refeita. Por fim, o orador ressalta o fato de o bom cidadão estar sempre preparado para defender a cidade, nunca a abandonando num momento de crise.

Em torno desse último aspecto está a argumentação central do discurso Contra Leócrates de Licurgo, único discurso completo do corpus desse orador que desempenhou um papel importante na política de Atenas. O discurso é a respeito do crime de alta traição contra a cidade cometido por Leócrates, que é acusado de abandoná-la diante de uma invasão iminente:

Para cúmulo, Cidadãos, deu-se o caso de Leócrates: com a cidade assim presa dos maiores temores, de imensos perigos e de enorme humilhação, este homem, sem pegar em armas em defesa da pátria, sem ir ter com os estrategos para o alistarem, desertou, pôs-se em fuga, atraiçoou a salvação do seu povo!

Os personagens dessa contenda são Licurgo e Leócrates, representados de maneira antagônica, em uma polarização do bom e do mau cidadão. Logo no início do discurso, já é possível perceber a estratégia de Licurgo de se autorrepresentar como um bom cidadão ao explicitar os motivos para processar seu adversário. Segundo ele, essa ação não parte de um desejo

7 Aeschin. 3. 196; Lycurg. 1. 4.

8 D. 21. 126. Esse discurso tem como um dos principais pontos de estratégia persuasiva a utilização das leis e seu sentido utilitário, com a demonstração de sua importância para o regime democrático.

9 Lycurg. 1. 43. Para as citações do discurso, utilizaremos a tradução de Campos (2010). 
individual de resolver uma rivalidade de âmbito privado, mas é o fruto do desejo de defender a cidade, trazendo o culpado à justiça para ser condenado. Sua argumentação vai além, na afirmação de que qualquer um ao cometer um crime contra a cidade torna-se inimigo pessoal do bom cidadão:

Um cidadão justo não deve levar ao tribunal, obedecendo apenas a alguma pessoal hostilidade, quem nenhum crime cometeu contra a cidade; muito pelo contrário, deve considerar como inimigo pessoal qualquer infractor das leis pátrias e pensar que os crimes contra a comunidade afectam todos os cidadãos e por isso mesmo justificam a total rejeição dos criminosos. ${ }^{10}$

Sobre o alvo dos ataques, Leócrates, sabe-se que era um comerciante ateniense e possuía também uma oficina de metalurgia que funcionava com trabalho escravo. Seus rendimentos advinham da oficina e dos juros cobrados do comércio de cereais. ${ }^{11}$ Após a Batalha de Queroneia e a derrota dos atenienses, Leócrates foge para Rodes com medo de Atenas ser invadida pelos macedônicos. Ele não parte sozinho, pois sua hetaira, de nome Irénide, também o acompanha e ele leva consigo parte de seus bens - alguns escravos e todo o dinheiro que conseguiu reunir na pressa da fuga. A descrição de sua evasão já indica um traço de caráter, que será explorado em outros momentos do discurso. Segundo Licurgo, Leócrates é um covarde, escolheu fugir como se fosse um criminoso. Ele sai da cidade ao cair da noite, escapando em um pequeno navio previamente preparado e que lhe aguardava no Pireu, ${ }^{12}$ indicando a premeditação do ato. Não satisfeito em abandonar a cidade num momento de dificuldade, ainda a prejudica, pois, ao chegar a Rodes, amedronta os comerciantes, dizendo que o Pireu havia sido invadido e ele era o único que conseguira escapar. Diante dessa informação, que o orador sempre enfatiza como mentirosa, os comerciantes de Rodes ficam temerosos e desistem de seguir viagem para Atenas. ${ }^{13}$

10 Lycurg. 1. 6. Para mais exemplos dessa operação retórica vide D. 21. 62, 74-75, 250; Aeschin. 1. 9-15.

11 Lycurg. 1. 58 .

12 Lycurg. 1. 17

13 Lycurg. 1. 18-20. 
Esse anúncio depois vem a lesar o próprio Leócrates, pois ele passa a enfrentar dificuldades na cidade, logo após a descoberta por parte dos comerciantes de que o Pireu estava funcionando normalmente e eles não precisavam suspender suas atividades. Leócrates passa a ser pressionado pela população local e, por isso, fica pouco tempo em Rodes, mudando-se em seguida para Mégara, cidade localizada na fronteira com Atenas. Esse fato, na visão do orador, aumenta ainda mais a afronta do adversário à terra natal, por ele ter a audácia de estar tão próximo dela depois de tê-la prejudicado. Em Mégara, Leócrates passa a se dedicar ao comércio de cereais por aproximadamente seis anos. Nesse ínterim, solicita ao cunhado, casado com sua irmã mais velha, e a um amigo que vendam todos os seus bens restantes em Atenas. Com o montante do dinheiro levantado, os dois deveriam quitar os credores antigos de Leócrates em Atenas e o que sobrasse deveria ser enviado a ele em sua nova morada. ${ }^{14}$ Entretanto, ele não leva para Mégara apenas seus bens, mas também o altar familiar, o que caracteriza uma ofensa grave contra a cidade por ser um grande desrespeito à esfera sagrada, pois, na religião grega, os elementos que compõem o altar familiar possuem uma profunda relação com a terra e não propriamente com os membros dessa família. Isso significaria, por conseguinte, levá-los para outra cidade e forçar as divindades a compactuar com o exílio forçado. ${ }^{15}$

Depois desses anos afastado, Leócrates volta a Atenas. Não se sabe ao certo as razões de seu retorno, sendo a hipótese mais provável o aparecimento de novas possibilidades de negócios. Ao deixar Atenas, ele perdera todos os direitos de um cidadão, além de ter ficado impossibilitado de cumprir seus deveres. Longe de sua terra natal, um cidadão não pode participar das decisões da esfera política, das festividades religiosas, das batalhas para proteger a cidade, elementos fundamentais na caracterização do papel do cidadão na democracia ateniense. Sendo assim, o exílio, voluntário ou não, significava a morte simbólica do cidadão.

14 Lycurg. 1. 21-24.

15 Esse aspecto é explorado em vários momentos do discurso: Lycurg. 1. 25-26, 35, 38, $56,97,128,142$. 
Após o retorno de Leócrates, Licurgo esforça-se para evitar o usufruto dos direitos e deveres da cidadania por seu adversário, caracterizando-o diante dos demais concidadãos como alguém sem nenhuma preocupação com a cidade, tendo o único interesse de proteger seus bens pessoais. Também ressalta os vários delitos cometidos por ele, indicando seu desrespeito às leis instituídas pela cidade:

Por mim, Cidadãos, entendo que sobre todos estes crimes tão nefastos e lamentáveis o voto não pode ser senão um, pois de todos os artigos da acusação Leócrates é convencido culpado: de traição, uma vez que deixou a cidade entregue às mãos dos inimigos, de tentativa de derrubar a democracia, uma vez que não afrontou o perigo de perdermos a liberdade, de sacrilégio, uma vez que pela sua parte foi culpado de os recintos sagrados serem saqueados e os templos destruídos, de ultraje aos antepassados, uma vez que não impediu a destruição dos túmulos e a interrupção dos rituais, de deserção e recusa a servir no exército, uma vez que não se apresentou aos estrategos para ser alistado. ${ }^{16}$

O trecho acima corresponde à peroração do discurso e sintetiza as principais acusações e razões para considerar Leócrates um mau cidadão. Ele é traidor por ter deixado a cidade nas "mãos dos inimigos", que visavam a acabar com a democracia, fato que não ocorreu. Na construção de sua estratégia retórica, o ato de Leócrates é equiparado aos dos demais traidores da democracia, já que a lei ateniense era muito severa nesse ponto, prevendo até mesmo a legitimidade do assassinato de quem favorecesse a tirania ou tentasse destituir a democracia. ${ }^{17}$ Ao utilizar essa relação, o orador está apelando para a construção da representação da democracia como a antítese da tirania. ${ }^{18}$ Ele também mexe com as lembranças traumáticas dos golpes oligárquicos em 411 a.C. e 404 a.C., retratados como momentos de extrema violência e arbitrariedade, além de esvaziamento da participação popular,

16 Lycurg. 1. 147.

17 Lycurg. 1. 125.

18 Canfora 2015: 404. 
pois havia o receio generalizado de ser assassinado caso se agisse contra as decisões centrais.

Ainda no trecho acima, verifica-se o uso de um esforço imaginativo do orador, apresentando suposições como fatos verdadeiros, principalmente no que se refere à esfera sagrada. Ele afirma que as ações de seu adversário poderiam deixar os templos desprotegidos e provocar a descontinuidade dos rituais, pois, sem um número suficiente de cidadãos, os templos ficariam à mercê de uma ofensiva. Historicamente, sabe-se que a ação de Filipe II não destruiu os templos atenienses e muito menos devastou a cidade. Esse exagero serve para agravar o ato de deserção de Leócrates, que o fez num momento de iminente invasão, quando a cidade mais precisava da proteção de seus cidadãos. O exagero remete ao medo de que Filipe II agisse da mesma forma que os Persas no ataque de 480 a.C., em que a Acrópole foi ocupada e templos e outras construções destruídos.

Licurgo faz essas graves acusações contra Leócrates. Ele pertencia à aristocracia e exercia um importante papel na cena pública de Atenas. Dedicou-se ao estudo da retórica como todo bom democrata segundo a visão de Ésquines, frequentando a academia de Platão e depois a escola de Isócrates. ${ }^{19}$ Durante sua vida foi um fervoroso defensor do regime democrático, da liberdade e da autonomia de Atenas. Era avaliado pelas fontes da época e posteriores como um excelente orador e uma pessoa honrada. ${ }^{20}$ Ele, juntamente com Demóstenes, via com várias ressalvas a expansão macedônica e o aumento de sua influência na Ática. Licurgo, antes da batalha de Queroneia, assume o cargo de tesoureiro dos rendimentos públicos (dioikesis ton kbrematon) ${ }^{21}$ e com suas reformas consegue aumentar o tesouro público, que estava exaurido desde o fim da Guerra do Peloponeso. Além disso, também esteve à frente de várias obras públicas, principalmente no teatro, onde supervisionou a construção de estátuas em homenagens a Ésquilo, Sófocles e Eurípides, e a preparação de textos das tragédias para

19 Plut. Vit. Dec. 841a.

20 Cf. Hyp. 4. 12.

21 Segundo os registros que chegaram à posterioridade, esse cargo deveria ser extraordinário, não constituindo parte da rotina da administração da cidade até então. O cargo não é listado na Constituição dos Atenienses pertencente ao corpus aristotelicum. 
serem arquivada no Metrôon, templo da mãe dos deuses, Cibele, que funcionava como um arquivo oficial da cidade. ${ }^{22}$ Licurgo também exerceu o cargo de policiamento da cidade, perseguindo os culpados com severidade, além de levar ao tribunal figuras importantes, representando a todos como maus cidadãos. ${ }^{23}$

Dessa maneira, segundo a indicação das fontes, Licurgo era um bom orador e um cidadão extremamente comprometido com os negócios públicos, conduzindo-os de forma habilidosa. Pelo menos foi essa a imagem que ele construiu de si mesmo e utilizou para garantir apoio dos cidadãos em suas ações. ${ }^{24}$ Para justificar sua ação contra Leócrates, ele afirma que tal fato seria feito por qualquer cidadão, pois seu maior interesse é a defesa da democracia e daquilo que é mais caro a ela, ou seja as leis e seus costumes: "o meu propósito é proteger a pátria, os seus cultos e as suas leis; cumpri o meu dever escrupulosamente e em obediência à justiça, não injuriei o comportamento privado deste homem, não me referi a nada excepto o que estava consignado no acto de acusação". ${ }^{25}$

No discurso, a construção da imagem do cidadão se dá a partir de dois eixos: suas ações dentro da polis, principalmente no que se refere aos assuntos públicos, e suas relações com outros membros da cidade. Assim, a identidade de um cidadão era construída a partir do valor atribuído pelos seus pares e, para expressar isso, podemos utilizar Vernant, ao afirmar que para os gregos, "é-se o que os outros veem". ${ }^{26}$ Canfora também adota a mesma perspectiva, ao expressar que um cidadão, independentemente de sua posição social, era vigiado pelos outros, sendo as ações de um cidadão objeto de conhecimento dos demais. ${ }^{27}$

Assim, pode-se considerar que, no jogo de poder travado na democracia ateniense, a grande parte dos habitantes da polis conhecia aspectos da vida

22 Cf. Plut. Vit. Dec. 841a e Paus. 1. 29. 15-16.

23 Licurgo conseguiu a condenação de Autólico e Lísicles. Além disso, moveu processos contra Licofron e Aristogíton. Para mais informações vide Campos 2010: 39.

24 Cf. Lycurg. 1. 5, 28, 36, 140, 149

25 Lycurg. 1. 149.

26 Vernant 1994: 20.

27 Canfora 2015: 509. 
privada e pública de outros cidadãos, ainda mais quando esses se destacavam na esfera política. O orador dá indício desse aspecto no discurso, quando sugere aos juízes como proceder diante dos dois tipos de cidadãos: "atenienses, é vosso dever, em vista do que vos disse, não apenas elogiar e honrar os bons cidadãos, mas igualmente odiar e punir os maus, muito em especial este Leócrates, que não mostrou perante vós nem medo nem respeito". 28 Segundo Licurgo, os bons cidadãos deveriam obter a absolvição dos juízes não por serem bons, mas por serem inocentes, estando presentes no tribunal devido a uma tentativa de algum adversário de incriminá-los. Assim, a absolvição estaria de acordo com os princípios da justiça. O bom cidadão é caracterizado por sua participação ativa nos negócios da cidade, respeitando sempre suas leis, costumes e todos os ritos que envolvem a esfera sagrada. Já o mau cidadão faz o oposto, estando mais preocupado com seus negócios particulares e desrespeitando as leis para atingir seus objetivos pessoais. A condenação do mau cidadão não está apenas ligada ao crime em discussão na ação jurídica, mas principalmente ao ato de fazer justiça pelos crimes impunes do passado, reparando assim toda a ação nefasta realizada contra a cidade.

Os juízes são elevados à categoria de bons cidadãos ao realizar seu voto de acordo com a justiça. Além disso, o voto tem uma função exemplar, ditando modelos do que é aceitável e condenável, principalmente aos mais jovens, ${ }^{29}$ que num futuro próximo estarão exercendo plenamente suas funções cívicas. Dessa forma, o juiz tem o dever de portar-se como bom cidadão:

Duas formas úteis existem para educar a juventude: uma, a punição de quem pratica uma injustiça, outra, a recompensa atribuída aos homens de bem; atentando nos respectivos exemplos, os jovens tenderão a evitar o primeiro movidos pelo medo, e a imitar o segundo por ânsia de boa reputação. Deveis,

28 Lycurg. 1. 74.

29 Leite 2014: 270-271. 
portanto, Atenienses, dar toda a atenção a este processo, tendo acima de tudo o propósito de fazer justiça. ${ }^{30}$

Adiante, a questão do exemplo aos jovens e de como eles devem se comportar assume traços religiosos na narrativa da erupção vulcânica no Etna. ${ }^{31}$ Quando o vulcão explode, os moradores da cidade correm para salvar suas vidas sem se preocupar com os outros, menos um jovem, que, vendo o pai em dificuldade, volta para socorrê-lo. Ele o coloca sob seus ombros, mas, devido ao peso não consegue se locomover rapidamente e ambos são cercados pela lava. Nesse momento, os deuses, ao fazer um círculo para impedir o avanço da lava, os protegem. Para Licurgo, o fato é a comprovação de que os deuses sempre recompensam os bons cidadãos e, ao finalizar o relato, pede a condenação de seu adversário por não ter respeitado a esfera sagrada com sua fuga, desconsiderando todos os elementos relacionados à constituição do sentimento de piedade (eusebes): a atenção aos deuses da cidade, o cuidado com os pais na velhice e as honras fúnebres.

Daqui se conclui que deveis basear-vos no testemunho dos deuses e, por unanimidade, determinar punir este homem, que, pelo seu comportamento pessoal, se tornou culpado dos maiores crimes. Privou os deuses pátrios das honras a eles devidas, deixou os progenitores à mercê dos inimigos, não prestou aos mortos os deveres que o rito prescreve. ${ }^{32}$

O retorno ao exemplo do passado é recorrente no Contra Leócrates, havendo uma valorização dele e dos bons feitos realizados pelos antepassados. O orador escolhe cuidadosamente apresentar para os juízes numerosos modelos de como deve agir o bom cidadão presentes na literatura grega e na história da cidade, ${ }^{33}$ com a função retórica de relembrar-lhes o seu papel cívico e exemplar.

30 Lycurg. 1. 10

31 Lycurg. 1. 95-96.

32 Lycurg. 1. 97.

33 Para a lista das citações poéticas e dos exemplos históricos presentes no discurso vide Campos 2010: 83-84. 
Uma maneira de explicar o uso excessivo de exemplos do passado é partir da contextualização da obra. O discurso é datado de aproximadamente 330 a.C., momento de fragmentação do Império ateniense, que, ao longo do século V a.C., havia consolidado uma certa maneira de se fazer e agir na democracia. Esse fazer e pensar estava enraizado de forma tão profunda que deixou ecos no século seguinte.

Mais especificamente, o discurso foi escrito logo após o fracasso dos atenienses na Batalha de Queroneia. Depois da derrota, a cidade ficou à mercê de Filipe II e diante da possibilidade de ser devastada, ${ }^{34}$ o que não se concretizou. Além disso, ainda estava na memória, coletiva e individual, dos atenienses as perdas em decorrência da derrota na Guerra do Peloponeso. Aos poucos, a cidade tentava se reerguer. O período do final do século $\mathrm{V}$ a.C. até o século IV a.C. foi muito conturbado, marcado pela intensificação dos conflitos políticos e sociais com o uso da violência e de uma grave crise econômica. ${ }^{35}$ No discurso, o parágrafo 42 sintetiza essas transformações sofridas pela cidade e a perda de sua hegemonia no Mediterrâneo:

Tão grande foi a mutação ocorrida em Atenas: uma cidade que outrora combatera pela liberdade de todos os Gregos, contentava-se agora em tentar lutar pela própria salvação com garantia de sucesso; ela, que antes dominava grandes extensões de território bárbaro, via-se agora constrangida a disputar o seu aos Macedónios; e o povo a cujo auxílio os Lacedemónios, os Peloponésios e os Gregos da Ásia Menor anteriormente recorriam está agora obrigado a solicitar a ajuda de Andros, de Ceos, de Trezene e de Epidauro. ${ }^{36}$

A Batalha da Queroneia inaugura o processo helenístico e a transformação dos valores que guiavam o sistema da polis. Esse processo de transformação é demonstrado tanto nas palavras do discurso quanto no seu resultado final: a absolvição de Leócrates pelo empate do voto dos juízes. ${ }^{37}$ O empate é

34 Aeschin. 3. 132-4.

35 Campos 2010: 43.

36 Lycurg. 1. 42.

37 No registro de Ésquines (3. 252) encontra-se uma referência ao caso de Leócrates e sua absolvição pelo empate na votação dos juízes. 
indicativo de dois fenômenos. O primeiro, que uma grande parcela dos cidadãos atenienses não considerava mais tão grave colocar os interesses pessoais acima dos coletivos, evidenciando uma certa noção de individualismo, que se aprimora no período helenístico, como demonstram as correntes filosóficas do epicurismo e estoicismo. O segundo, que o argumento retórico da polaridade entre o bom e mau cidadão ainda se mantém forte, principalmente como um componente importante na construção do ethos do orador e de seu adversário.

A própria vida de Licurgo é um baluarte do ethos do bom cidadão e seu prestígio pode ser elencado como um dos fatores atrativos para conquistar a simpatia dos juízes. ${ }^{38}$ Demóstenes, ao escrever uma carta em defesa dos filhos de Licurgo, após sua morte, confirma a construção desse ethos: "tínheis mesmo tanta confiança nele, no seu estatuto de exemplar democrata, que em muitos processos bastava conbecer a opinião de Licurgo para formulardes um justo juízo, o que não sucederia se não désseis tanto valor à sua palavra". 39

A importância da construção desse ethos ganha ainda mais força no discurso pela estratégia persuasiva escolhida por Licurgo no Contra Leócrates. Ele opta por não utilizar muitas citações de leis que forneceriam suporte para a acusação. Por exemplo, não há nenhuma menção ao nomos eisangeltikos ou à lei que proibia qualquer cidadão ateniense de comercializar trigo com outra cidade que não fosse Atenas, ação cometida por Leócrates ${ }^{40}$ e que em termos pragmáticos era mais fácil de se demonstrar do que o crime de deserção e traição.

Se observamos a estratégia persuasiva do orador de utilizar variados exemplos que comprovem o agir corretamente do cidadão e auxiliem a construção do ethos do bom cidadão, veremos que ele está de acordo com a proposta de Aristóteles em seu tratado de Retórica. ${ }^{41}$ De acordo com o filósofo, a eficácia da persuasão está relacionada com o caráter apresentado pelo orador, que consegue cultivar a confiança de sua audiência: "persuade-se pelo caráter quando o discurso é proferido de tal maneira que deixa a impressão de o orador

38 Campos 2010: 88.

39 D. Ep. 3. 6. Para as citações da Carta, utilizaremos a tradução de Campos (2010).

40 Lycurg. 1. 27.

41 Aristot. Rh. 1365 b. 
ser digno de fé. Pois acreditamos mais e bem mais depressa em pessoas honestas, [...] o caráter é o principal meio de persuasão". ${ }_{42}$

Outro mecanismo para persuadir a audiência, também abordado por Aristóteles no dito tratado, é a demonstração de conhecimento sobre o funcionamento do governo por parte do orador. Dessa maneira, um bom orador deve conhecer as formas de governo para construir argumentos que demonstrem a preservação do regime.

Licurgo utiliza-se dessa estratégia e enumera os fatores importantes para a preservação da democracia:

São três os factores mais importantes para a preservação e a manutenção da democracia e da harmonia entre os cidadãos: primeiro, a ordenação jurídica, segundo, o voto dos juízes, terceiro, o processo que leva os culpados a julgamento. A lei, por natureza, estabelece o que é proibido fazer-se, o acusador denuncia os que caem sob a alçada das leis penais, o juiz castiga aqueles que lhe são apresentados pelos dois outros componentes: quer isto dizer que a lei e o voto dos juízes não teriam qualquer poder se não houvesse quem lhes desse a conhecer os prevaricadores. ${ }^{43}$

Ao enumerar esses fatores, o orador espera de sua audiência uma noção de como é viver em uma democracia, destacando aquilo que julgava importante para essa convivência, a começar pelas leis e sua obediência por parte dos cidadãos, pois são guias de conduta e asseguram a preservação do regime, ditando o agir correto. ${ }^{44} \mathrm{O}$ orador ainda ressalta que as leis somente têm validade quando seguidas, por isso o voto dos juízes é tão importante, pois é por meio do veredito que a lei se transforma em ação. Outro aspecto essencial é o reconhecimento da participação do demos nas instituições democráticas. Em conjunto, os cidadãos decidem o destino daqueles que cometeram algum mal à democracia, desde delitos pequenos a graves, como o de Leócrates na perspectiva de Licurgo. O orador também

42 Aristot. Rh. 1365a. Para as citações do tratado, utilizaremos a tradução de Alexandre Jr. (2005).

43 Lycurg. 1. 4.

44 D. 21. 34, 76. 
reforça a importância do cumprimento individual dos deveres por parte dos juízes, já que, quando um cidadão falha, ele se torna responsável por todo o mal que pode suceder na cidade: "toda a cidade confia, para a sua preservação, na vigilância exercida por cada um dos seus habitantes; quando alguém falba o cumprimento de um dever, num aspecto só que seja, está a pôr em causa, ainda que inconscientemente, o cumprimento de todos os demais". ${ }^{45}$ Por pensar somente nos seus interesses e abandonar a cidade, Leócrates a deixa vulnerável, sendo merecedor da pena capital. ${ }^{46}$

Segundo Aristóteles, o tema da preservação do regime é sempre de interesse de todos da cidade. Colocando em prática esse raciocínio, em Atenas um orador deveria conhecer bem o funcionamento da democracia e mostrar sintonia com seus princípios norteadores. Talvez isso explique por que no discurso Licurgo não somente lista os mecanismos necessários para a preservação da democracia, mas também enumera os elementos que a formam: o cidadão na esfera privada e no desempenho de suas funções legislativas e judiciárias.

São três os elementos constitutivos do Estado: o magistrado, o juiz, o cidadão privado. Cada um deles compromete-se a cumprir este juramento. Tem havido decerto muitos que conseguiram iludir e manipular os concidadãos, escapando assim não só aos perigos presentes, mas passando mesmo o resto da vida sem sofrerem o castigo dos seus crimes. ${ }^{47}$

Observa-se que não são os locais ou instituições que são elencados, mas sim as funções que o cidadão desempenhava na democracia, num claro movimento de valorização da participação dos cidadãos e de reforçar suas responsabilidades para com o regime. O bom cidadão não deve se preocupar somente com os aspectos da sua vida privada, mas deve sempre participar do governo da cidade, assumindo seu compromisso e reafirmando suas obrigações cívicas.

45 Lycurg. 1. 64

46 Lycurg. 1. 5, 123.

47 Lycurg. 1. 79. 
Na Retórica, Aristóteles atribui como característica importante da democracia a distribuição de cargos por sorteio, sendo o principal objetivo do regime assegurar a liberdade. ${ }^{48}$ A temática da liberdade também aparece em um outro tratado do filósofo, ${ }^{49}$ o que evidencia a importância dessa noção para a democracia. Assim, segundo a teoria aristotélica no que diz respeito à retórica, o elemento mais característico de cada regime também será aquele que terá maior impacto na audiência, ou seja, que será o mais persuasivo. Pensando nesses termos, pode-se entender melhor o uso da palavra liberdade (eleutheria) no Contra Leócrates, que tem um total de doze ocorrências. ${ }^{50}$

A leitura do discurso indica adoção por parte do orador de uma concepção de liberdade, na qual ela deveria ser exercida em termo coletivos. Há uma condenação da liberdade pessoal quando esta coloca em risco a cidade, e é justamente nesse aspecto que está a condenação de Leócrates por parte de Licurgo, como exemplifica seu pedido: "acaso algum deles se disporia com o seu voto a acusar de loucura quantos sacrificaram a vida pela liberdade e deixar impune o traidor da pátria como se fosse um cidadão exemplar?"

$\mathrm{Na}$ democracia ateniense, o sujeito só existe enquanto membro do demos. Não há, como nas democracias contemporâneas, uma defesa da liberdade, da autonomia e do respeito individuais. Por isso, na Antiguidade a liberdade a ser assegurada é a da polis, em que os cidadãos devem estar dispostos a sacrificar sua vida por ela. Para usufruir dessa liberdade coletiva, o cidadão tem que ser responsável por seus atos. Nas palavras de Campos, o cidadão deveria exercer uma responsabilidade ética nas relações com outros cidadãos, o que implica obediência à lei e aos costumes, e uma responsabilidade histórica, para defender a memória daqueles que morreram pelo regime,52 como é explícito no discurso a partir da inserção do "Juramento de Plateias", em que a liberdade, obediência e defesa da cidade são valores que se sobrepõem à própria vida: "não darei mais valor à vida do que à liberdade,

48 Aristot. Rh. 1366 a.

49 Aristot. Pol. 1317a.

50 Campos 2010: 49.

51 Lycurg. 1. 144.

52 Campos 2010: 137. 
não abandonarei os meus chefes, vivos ou mortos, mas darei sepultura a todos os aliados mortos em combate". 53 Sobre esse último aspecto, Licurgo também explora a morte dos combatentes em Queroneia, equiparando-os a defensores da liberdade. ${ }^{54}$

A liberdade é tão importante para a democracia que ela está presente em uma de suas noções basilares, a isegoria. Este princípio indica que qualquer cidadão poderia tomar a palavra nas instituições democráticas. De acordo com Licurgo, a democracia dá toda a liberdade para os oradores falarem e, por isso, eles podem contar mentiras, enganando os juízes. Então, os ouvintes não devem guiar suas ações apenas por meio das palavras, mas principalmente mirar nos melhores exemplos, que são representados pela instituição do Areópago: "[...] dais toda a liberdade retórica aos oradores que vos falam, quando tendes no conselho do Areópago um belíssimo exemplo para todos os Gregos, um tribunal tão superior a qualquer outro que até os condenados reconbecem a justiça das suas sentenças". ${ }^{55}$

Ao fazer a relação entre liberdade, poder e retórica, o orador demonstra e reconhece a importância dessa relação para a democracia e como esses elementos fazem parte dos jogos de poder do regime democrático, pois nele as decisões ocorrem por meio da palavra. A palavra é o primeiro passo para a ação política, que se dá por meio da persuasão. ${ }^{56}$ A decisão, que levará à ação política, só ocorre depois da reunião do grupo de cidadãos para discutirem e ouvirem as diversas posições sobre o assunto, para depois deliberarem em um processo de escolha majoritária.

Como o princípio majoritário regulamentava todas as decisões, nota-se o empenho dos oradores em conseguir o maior número de votos. Sendo assim, cada vez que um discurso era pronunciado, fosse na assembleia ou no tribunal, uma batalha era travada. O clima de tensão sempre cercava os oradores. ${ }^{57}$ Eles estavam à espera da aprovação de sua proposta por meio dos votos dos cidadãos e, por isso, eles tentavam assegurar numa determinada

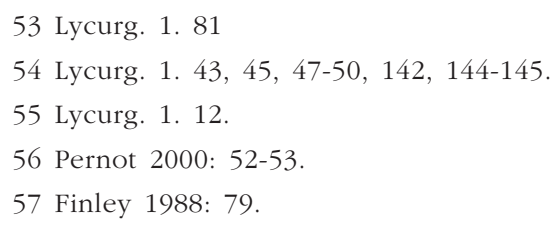


camada da população a lealdade e a motivação para suas propostas. Para esse fim, era importante construírem a respeito de si o ethos do bom cidadão. O próprio exemplo de Licurgo indica essa prática na cidade, mesmo no século IV a.C., pois ele conseguiu persuadir metades dos juízes.

Todas as instituições na democracia ateniense eram marcadas pelo conflito, mas o tribunal se destacava por permitir um embate direto dos inimigos, ou às vezes indireto, em ataque a outros membros do grupo político adversário, sem haver qualquer interrupção. Essa condição tão favorável ao discurso não acontecia na assembleia, pois havia a possibilidade de o discurso ser interrompido pelo barulho dos adversários. ${ }^{58} \mathrm{Na}$ opinião de Canfora, o tribunal é o espaço onde a democracia ocorre de forma mais direta. Em sua argumentação, ele defende que, nos séculos V a.C. e IV a. C., o tribunal ocupou uma posição equivalente ou superior à assembleia e ao teatro na dinâmica da democracia ateniense. 59 Tal posição é arriscada, pois não considera de forma apropriada as relações dinâmicas entre as instituições, já que há casos de desavenças que começaram na assembleia e foram para o tribunal e vice-versa. O caso mais emblemático dessa dinâmica é o embate entre Demóstenes e Mídias, em que a contenda perpassou as três instituições, sendo marcada pelo soco de Mídias em Demóstenes no teatro durante as Grandes Dionisíacas. ${ }^{60}$

Assim, a democracia é o regime em que a comunicação política é marcada pelo conflito e o debate sempre irá apresentar elementos controversos. ${ }^{61} \mathrm{O}$ instrumento para a comunicação política é a retórica. Dessa forma, o orador

58 Sobre a relação entre silêncio e oratória vide Leite 2014: 25-29.

59 Canfora 2015: 506.

60 Mídias e Demóstenes eram inimigos políticos e pessoais declarados. A inimizade entre eles inicia-se na juventude de Demóstenes, quando Mídias e seu irmão Trasíloco movem um processo de antidosis contra o orador para prejudicá-lo na ação contra seus tutores (Dem. 21.78). Depois disso, há vários processos e contra processos de um contra o outro, até o incidente das Grandes Dionisíacas em 348 a.C., quando ambos disputavam o concurso de coros ditirambo. Demóstenes, no Contra Mídias, argumenta que a agressão de seu adversário é uma ofensa ao sagrado por desrespeitar a festa em honra a Dioniso. Assim, ambos eram adversários nas assembleias, por defenderem perspectivas diferentes da relação de Atenas com a Macedônia, no tribunal e também no teatro.

61 Flaig 2013: 72. 
controla o que diz e também como diz e prevê qual será a reação da audiência, mas o resultado final não está sob seu controle. ${ }^{62}$

Na democracia, a palavra só ganha um sentido político se estiver no contexto da participação dos seus cidadãos. São eles que, reunidos, tomam as decisões para a cidade. As decisões deveriam seguir as leis e os costumes do regime e, para todos estarem cientes das leis, estas eram expostas em lugares públicos. O ato de deliberar em conjunto na esfera política foi citado por Licurgo para relembrar os juízes de que sua sentença deveria visar ao melhor para a cidade: "estas palavras, Cidadãos, foram gravadas na estela colocada nas instalações do Conselho para lembrar a quantos diariamente lá se reuniam para deliberar sobre o bem da pátria qual o modo adequado de tratar com gente desta". ${ }^{63}$

A deliberação exige um grande empenho psicológico e de confiança nos pares e no sistema político. Como duas partes estão em conflito, o ouvinte deve imaginar quais as consequências de cada proposta para o problema. Além disso, o orador deve cuidadosamente apresentar sua própria opinião, de forma convincente, e escutar com atenção as demais propostas, lembrando do que foi dito e separando os bons e maus argumentos para uma possível réplica. Todo esse sistema de comunicação demanda também muito tempo dos ouvintes, já que em alguns casos a deliberação poderia se arrastar por todo o dia. ${ }^{64}$

No contexto de participação e deliberação, o desenvolvimento do ideal do bom cidadão, além de ser um forte argumento persuasivo, também desempenha um papel importante na chamada "ideologia da democracia", conceito desenvolvido por Ober (2015) para explicar a democracia a partir dos símbolos e na capacidade destes de mover ações. Isso fazia com que a desigualdade da realidade fosse sentida de forma mais amena, já que, apesar do princípio da isegoria, poucos realmente discursavam, desempenhando um papel de destaque no jogo político, ${ }^{65}$ que acabava permanecendo nas mãos de famílias aristocráticas. Segundo o autor, em

62 Yunis 2013: 145

63 Lycurg.1. 126.

64 Flaig 2013: 84.

65 Leite 2014: 25-29. 
Atenas havia a "regra do igualitarismo", ${ }^{66}$ isto é, a maioria das pessoas de uma sociedade (e esse número tem que ser maior do que de pessoas pertencentes a elite) tem a mesma possibilidade de acesso às instituições do regime, o que é significativo e um diferencial até mesmo se compararmos aos regimes políticos contemporâneos. Assim, na democracia ateniense, os cidadãos são tratados como iguais nos cargos públicos e na esfera jurídica e, mesmo possuindo habilidades diferentes, têm as mesmas possibilidades de acesso aos cargos públicos. Mais do que a liberdade, os princípios da isocracia, isonomia e isegoria garantem ao cidadão o tratamento igualitário, seja no exercício do poder de qualquer cargo, nos julgamentos ou na possibilidade de fala. Ober ainda afirma que a democracia foi um sistema político e econômico excepcional, pois, além de conseguir promover o bem-estar da população também era assentado nos valores da liberdade, equidade e dignidade. Muitos desses valores também são o que desejamos para nossos governos atuais. ${ }^{67}$

Os oradores transmitem em seus discursos uma visão idealizada dos cidadãos, em que todo o demos se uniria para tomar a melhor decisão para a cidade. Licurgo, logo no início do discurso, mostra-se como um cidadão preocupado, colocando sua vontade (a condenação de Leócrates) em sintonia com a do demos, que para guiar seu voto deveria pensar não somente nele próprio, mas nos antepassados, nas gerações futuras, nas mulheres e em tudo que é fundamental para a democracia:

Fazei de mim neste dia um condigno acusador dos crimes de Leócrates, fazei que a minha palavra seja útil, e digna deste povo e desta cidade; e fazei que estes juízes, ao deliberar sobre o que devemos aos nossos pais, filhos e mulheres, à nossa pátria e aos nossos cultos, e tendo à mercê do seu voto este homem, que a todos traiu, se mostrem juízes implacáveis, hoje e sempre, de todos quantos tão grave e brutalmente desrespeitarem as leis. Se, porém, o homem que aqui acuso nem foi traidor à pátria, nem fugiu aos seus deveres

66 Ober 2015: 138.

67 Ober 2015: 13. 
cívicos e religiosos, peço-vos a vós, deuses, e a vós, seus futuros juízes, que o ilibeis neste processo. ${ }^{68}$

Outro momento em que o orador apela para a união do demos é quando cita o texto do "Juramento dos efebos". Neste trecho também é reforçado o papel de bom cidadão de Licurgo, pois ele fez parte da reforma da efebia, tornando sua estrutura mais rígida. ${ }^{69}$ Além disso, a citação desse juramento demonstra a importância da educação dos jovens e de seu papel na democracia. No juramento, nota-se aquilo que irá definir o bom cidadão: a obediência às leis, o respeito aos cultos familiares e da polis, a punição dos culpados e a disposição para defender a cidade em armas sempre que necessário, nunca abandonando o seu posto.

Não envergonharei as armas sagradas, não abandonarei o meu camarada de armas qualquer que seja o meu posto, defenderei os valores quer sagrados, quer cívicos, isolada e colectivamente; não transmitirei aos vindouros a pátria diminuída, mas sim maior e melhor do que a recebi. Obedecerei sempre às ordens dos chefes, cumprirei as leis em vigor e todas as que vierem a ser aprovadas pela comunidade dos cidadãos. Se alguém anular as leis, ou não lhes obedecer, não o ajudarei, mas tentarei impedi-lo, isolada ou colectivamente. Honrarei os cultos ancestrais. Garantes deste juramento serão os deuses Aglauro, Ares Eniálio, Zeus, Talo, Auxo Hegémone..$^{70}$

Assim, o bom cidadão é principalmente aquele que respeita a esfera divina, a tradição, a família e seus antepassados. Por não preencher nenhum desses quesitos e ainda ter abandonado a cidade, Leócrates merece a punição.

Sabeis bem, cidadãos de Atenas, quais os valores que sobretudo vos distinguem dos demais: o respeito para com os deuses, a piedade para com os

68 Lycurg. 1. 2.

69 Campos 2010: 90-92.

70 Lycurg. 1.77. 
progenitores, o orgulho na vossa pátria; dareis, portanto, a impressão de por completo os esquecer se deixardes este homem escapar à vossa punição.71

Já o mau cidadão demonstra o seu desdém pela cidade. Para enfatizar os erros cometidos por Leócrates ao abandonar a cidade, o orador faz um apelo emocionante, ao dizer que todos contribuíram para a defesa da cidade, não apenas os cidadãos, mas também os campos ao oferecer as madeiras das árvores, os mortos, o seu sepulcro, e os templos, as armas dadas em oferendas, demonstrando a gravidade da situação, pois os cidadãos evitavam de todas as formas utilizar as armas sagradas.

Que orador responderá ao seu apelo e auxiliará este traidor, que não partilhou com os outros a dor pela desgraça da pátria, que em nada contribuiu para a defesa da cidade e da democracia, quando até os campos ofereciam as suas árvores, os mortos os seus sepulcros e os templos as armas ofertadas?72

A maior parte do discurso se concentra na rejeição da postura de Leócrates, considerada individualista e inadequada para um cidadão. Ele, por ser um desertor, não deve ter os mesmos direitos de que gozam os cidadãos, preocupados em defender a cidade, principalmente por respeito à memória daqueles que perderam suas vidas em defesa dela, como os combatentes mortos em Queroneia.

Seria terrível e lamentável que Leócrates imaginasse terem os mesmos direitos, ele, o desertor, e aqueles que permaneceram em Atenas, ele, que não arriscou a vida, e aqueles que combateram, ele, que não permaneceu no seu posto, e aqueles que lutaram pela cidade, e que lhe fosse permitido vir agora participar nos nossos cultos, nos nossos sacrifícios, gozar da nossa ágora, das nossas leis, da nossa constituição - de tudo aquilo por cuja preservação morreram em Queroneia milhares de cidadãos que mereceram ser sepultados com honras de Estado! Este Leócrates, ao regressar à nossa cidade, nem

71 Lycurg. 1. 15.

72 Lycurg. 1. 43 
sequer se envergonha ao passar junto às inscrições tumulares, entende que pode passear-se com desfaçatez ante os olhares dos que choram a morte dos mortos na batalha. ${ }^{73}$

Em oposição, o bom cidadão, como já foi dito antes, está ciente de seus direitos e deveres e da exigência de serem cumpridos em prol da coletividade. Ele também é um bom orador que utiliza as palavras para defender tudo aquilo que é importante para democracia, em especial, a esfera religiosa e as leis.

O meu propósito é proteger a pátria, os seus cultos e as suas leis; cumpri o meu dever escrupulosamente e em obediência à justiça, não injuriei o comportamento privado deste homem, não me referi a nada excepto o que estava consignado no acto de acusação. Cada um de vós deve ter presente ao espírito que absolver Leócrates equivale a condenar a pátria à morte e à servidão. No tribunal há apenas duas urnas, uma é a da traição à pátria, outra a da sua salvação, uma receberá os votos pela destruição, outros os votos pela segurança e pela prosperidade da nossa cidade..$^{74}$

Assim, após a leitura do Contra Leócrates, concluímos que utilizar os discursos forenses como fonte para o entendimento do regime democrático é centrar o olhar para os tribunais de Atenas e de sua importância para este regime. Não há democracia na Atenas Clássica sem os tribunais. A organização do sistema jurídico, seus procedimentos e os tipos principais de argumentação ${ }^{75}$ refletem os aspectos importantes da ideologia democrática como a maneira correta de agir do cidadão. Os tribunais são instituições eficazes para manter a ordem, conservar as leis e promover a estabilidade

73 Lycurg. 1. 142.

74 Lycurg. 1. 149.

75 De acordo com Lanni (2013: 168-169) além das leis e juramentos há seis categorias que são citadas com frequências pelos oradores: (1) o tratamento dado a familiares e amigos, (2) a moderação como virtude, (3) honestidade e justiça no tratamento dos negócios, (4) lealdade nos serviços prestados a cidade (5) retidão na vida privada e, por fim, (6) obediência às leis da cidade. Deve-se notar que todas essas categorias reforçam o ideal de bom cidadão. 
política. ${ }^{76}$ Eles também evidenciam a participação dos cidadãos, já que o veredito era o resultado dos votos individuais dos juízes, convencidos a seguir determinada posição depois de considerar inúmeros fatores que nem sempre residiam estritamente na ordem legal, como, por exemplo, a construção do ethos do bom e mau cidadão. A democracia é marcada pela constante relação de duas figuras: o orador, que deve ser hábil com as palavras e interessado no bem da cidade, e o demos, que possui a liberdade e a soberania, exercendo-as através dos mecanismos de participação, sendo o voto um deles. ${ }^{77}$

Os discursos forenses demonstram o desenvolvimento de uma racionalidade política, em que o idealizado corresponde a uma reflexão a respeito da vida política. Esperava-se que todos os cidadãos se comportassem dessa forma, mas na realidade era provável que poucos conseguissem atingir os critérios, como ter um bom desempenho retórico e dinheiro para financiar os negócios públicos.

Dessa forma, a democracia, termo consolidado em nosso vocabulário político com conotações na maioria das vezes positivas, demanda uma intensa participação do cidadão. A democracia não significa necessariamente o governo da maioria, apesar de as decisões serem tomadas a partir do princípio do majoritário. Ela significa o poder pertencente ao demos e seu exercício com soberania nas instituições. Na própria Antiguidade, o conceito de democracia não foi estático, tendo, por exemplo, conotações negativas nas obras dos filósofos que condenavam a atuação do demos. ${ }^{78}$ Para esse grupo, um dos principais problemas da democracia consistia em se deixar conduzir por uma parcela da população que, sob o seu ponto de vista, era totalmente desqualificada para tomada de decisões políticas. ${ }^{79}$

Dessa maneira, estudar os discursos forenses é uma forma de perceber as permanências e rupturas nesse regime político em Atenas, que floresceu e alcançou a estabilidade em um período em que a Hélade é marcada por

76 Lanni 2013: 168 .

77 Campos 2010: 113.

78 Cf. Plat. Rep. 544C; Aristot, Pol. 1279a22.

79 Isso constitui uma das linhas principais da argumentação do opúsculo $A$ constituição dos Atenienses, que pertence ao corpus das obras de Xenofonte. 
vários conflitos e golpes de estado. Além disso, nos discursos, o demos é o principal protagonista, já que a ele é dada a responsabilidade pela condução do caso, sendo a decisão final obtida através do voto. Outro aspecto importante da participação do demos é seu papel como receptor de determinados padrões de comportamento, o qual ele convalida como correto, como podemos perceber a partir da repetição do mesmo padrão na construção do ethos do bom e do mau cidadão em diferentes discursos.

No Contra Leócrates, nos deparamos com um ideal de cidadania, que serve para refletirmos acerca da nossa postura na esfera política atual. Sendo assim, consideramos que a democracia ateniense é útil para nos auxiliar nos desafios diários inerentes aos regimes políticos. Um dos seus principais legados é assegurar a participação popular com sua decisão soberana nas instituições de poder, mesmo com todos conflitos que dela advenham, bem como a reivindicação de que a ação política sempre ocorra por meio das palavras. Deve-se sempre priorizar o discurso dialógico e não a utilização de outros mecanismos de força. Diante das incertezas que as democracias atravessam, é momento de relembrar esses dois legados - a participação popular e a soberania da palavra - e exercer a nossa cidadania.

\section{REFERÊNCIA BIBLIOGRÁFICA}

Alexandre Jr., M. (2005), Aristóteles. Retórica. Prefácio e Introdução. Lisboa.

Bruna, J. (1997), Eloquência grega e Latina. Seleção, tradução, introdução e notas liminares. Rio de Janeiro.

Campos, J. A. S. e (2010), Licurgo. Oração Contra Leócrates. Tradução do grego, introdução e notas. Coimbra.

Canfora, L. (2015), O mundo de Atenas. São Paulo.

Finley. M. I. (1988), Democracia: antiga e moderna. Rio de Janeiro.

Flaig, E. (2013), "To Act with Good Advice: Greek Tragedy and the Democratic Political Sphere", in J. P. Arnason, K. A. Raafaub, P. Wagner (org.). The Greek Polis and the Invention of Democracy. A Political-Cutural Transformation and its Interpretation. Chichester, 71-98.

Kury, M. da G. (1985), Aristóteles. Política. Tradução, introdução e notas. Brasília.

Lanni, A. (2013), "Law and Democracy in Classical Athens", i in J. P. Arnason, K. A. Raafaub, P. Wagner (org.). The Greek Polis and the Invention of Democracy. A Political-Cutural Transformation and its Interpretation. Chichester, 163-180.

Leite, P. G. (2014), Ética e retórica forense: asebeia e bybris na caracterização dos adversários em Demóstenes. Coimbra. 
MacDowell, D. M. (2002), Demosthenes. Against Meidias. Edited with Introduction, Translation and Commentary. London.

Mitchell, T. (2015), Democracy's Beginning: the Athenian Story. Yale.

Ober, J. (2015), The Rise and Fall of Classical Greece. Princeton-Oxford.

Pernot, L. (2000), La rhétorique dans l'Antiquité. Paris.

Trabulsi, J. A. D. (2006), Participation directe et démocratie grecque - Une histoire exemplaire? Besançon.

Vernant, J. P. (1994), "Introdução", in. J. P. Vernant (org.), O bomem grego. Lisboa, 7-22.

Yunis, H. (2013), "Political Uses of Rhetoric in Democratic Athens, in J. P. Arnason, K. A. Raafaub, P. Wagner (org.). The Greek Polis and the Invention of Democracy. A Political-Cutural Transformation and its Interpretation. Chichester, 144-162. 